\title{
コンクリートのひび割れ進展計測のための 画像解析手法に関する基礎的研究
}

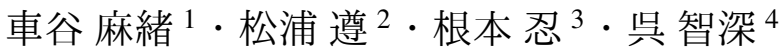 \\ 1正会員 茨城大学 工学部 都市システム工学科（† 316-8511 茨城県日立市中成沢町 4-12-1) \\ 2学生会員 東北大学大学院 工学研究科 土木工学専攻（９ 980-8579 仙台市青葉区荒巻字青葉 6-6-06) \\ 3学生会員 茨城大学大学院 理工学研究科都市システム工学専攻 ( ₹ 316-8511 茨城県日立市中成沢町 4-12-1) \\ 4 正会員 茨城大学 工学部 都市システム工学科（
}

\begin{abstract}
本論文では, 画像相関法における誤差を低減させ, かつ高解像度のグリッドでひずみ分布を計測するための 画像解析手法を構築し，コンクリートのひび割れ進展挙動の計測・可視化について検討する.コンクリートの 微細なひび割れを計測するには, 変位やひずみを測定するグリッドを高解像度にするとともに, ひび割れ形成 に伴う画像の乱れや複雑変位に起因する測定精度の低下を防ぐ必要がある.これらの問題に対して, 本論文で は, 検査領域の重複や階層化, 物質点の追跡と変位ベクトルの更新を実装した画像解析手法を構築した. 本手 法をモルタルおよびコンクリート供試体の圧縮試験に適用した結果，高精度にひずみを計測でき，目視て確認 できない微小なひび割れや, 粗骨材の影響による複雑なひび割れ進展挙動を計測可能であることを示した.
\end{abstract}

Key Words: image analysis, digital image correlation, crack propagation, mortar, concrete

\section{1.はじめに}

コンクリートは，荷重が作用して引張強度に達する と, 大小様々なひび割れが発生する. 発生したひび割れ は，部材の力学性能に影響を与えるだけでなく，目視で 確認できない微細なひび割れであっても，水分やイオ ンの移動経路となって部材の耐久性を低下させる．コ ンクリートに生じる変位やひずみの分布を計測し，ひ び割れ進展挙動を定量化することができれば，部材レ ベルでは損傷の判別に, 供試体レベルではコンクリー トの破壊機構の解明につなげることができる.

数值解析手法について研究する計算力学の分野では, 様々なひび割れ進展解析手法が提案されている ${ }^{1)}$. 破壊 の解析では領域中に不連続な境界が発生するうえ，コ ンクリートの場合は材料の不均一性に起因して, 破壞 進行領域を伴いながら準脆性的にひび割れが発生・進 展することから，一般にコンクリートのひび割れ進展 挙動を数值解析で再現するのは容易ではない. 実験結 果から, 破壞進行領域や微細ひび割れ挙動を計測・可視 化することも容易な作業ではないため, ひび割れ進展 解析に対する妥当性の検証（V\&V） 2) も進んではいな い、ひずみ分布を計測する技術の高度化によって，目 視できない微細ひび割れから巨視的なひび割れへの成 長を可視化することができれば，コンクリートのひび 割れ進展解析の高度化にも寄与することになる。

部材や材料の変形を計測する方法として, ひずみゲー ジによる接触式の計測方法がある。この方法は, 適切
な条件のもとで信頼性の高い計測を行うことができる. しかし，ひずみゲージによって計測されるひずみは，ひ ずみゲージを貼付した箇所での一方向のひずみである ので，計測対象全域に分布する多方向のひずみを計測 し，可視化することはできない. コンクリートの場合， ひび割れの発生個所をあらかじめ予測して，ひずみゲー ジを貼付することは困難なうえ, ひび割れの発生・進 展により, 時々刻々と変化するひずみ分布をひずみゲー ジで計測することは不可能である.

近年, 接触式の計測法に代わる方法として, 非接触 で全視野計測が可能な計測手法が注目されている. 代 表的な方法として，スペックル干渉を利用した方法 ${ }^{3}$, デジタル画像を利用した方法 ${ }^{4)}$ がある. 特に, デジタ ル画像を利用した方法では, 変形前と変形後における 部材や供試体のデジタル画像を撮影するだけで, 変位 を計測でき, 変位からひずみ分布を求めることができ る. 主な方法として, 粒子追跡法（格子法） ${ }^{5)}$ と画像 相関法 ${ }^{6)}$ がある. 格子法は, 計測対象に格子点を設け, デジタル画像をもとに格子点の変位を追跡する方法で ある. 適用事例として, 鉄筋コンクリートはりの載荷 実験中に，リアルタイムでひずみ分布を可視化する方 法が報告されている7). 画像相関法は, デジタル画像 における輝度值分布のランダム性を利用して, 変形前 後のデジタル画像から, 輝度值パターンの移動を相関 関数を用いて求める方法である。この方法は, 計測精 度や解析方法に関する拡張性が高いため, これまでに 地盤材料 ${ }^{8)}$, 石亳 ${ }^{9)}$, コンクリート 10),11),12) など, 様々 
な材料の変形計測に適用されている.

コンクリートに画像相関法を適用する際, 載荷過程 でコンクリートにひび割れが発生・進展しても, 安定的 に高解像度でひずみ分布を計測可能な画像解析手法を 適用する必要がある。コンクリートにひび割れが発生 すると, 不連続面の形成や応力の再分配により画像の 乱れや回転変位が生じる可能性がある。これらは，一 般に, 画像相関法の精度の低下を引き起こす。また, 目 視では判別できない微細なひび割れを計測する場合に は, 測定グリッドの解像度を高くする必要がある。し かし, 画像相関法では, 測定グリッドの解像度を高く すると, 輝度值パターンの相関を評価する検査領域が 小さくなり, 輝度值パターンの個性がなくなることに よって, 正確でない変位ベクトルが検出される。コン クリートのひび割れ進展計測に画像相関法を適用する 際は, このような問題が発生しないように, 検査領域 の取り方, 測定点の解像度, 変位ベクトルの計算法を 検討する必要がある.

そこで本研究では, 画像相関法における誤差を低減 させ，かつ高解像度のグリッドでひずみ分布を計測す るための画像解析手法を構築し, コンクリートのひび 割れ進展挙動の計測・可視化について検討する. 具体 的には, 画像相関法における検査領域の重複や階層化, 物質点の追跡と変位ベクトルの更新を画像解析に実装 し, モルタル供試体とコンクリート供試体の圧縮試験 の結果について比較・検討する.

第 2 章では, 本研究で構築した画像相関法に基づく 画像解析手法について説明する. 高解像度のグリッド でひずみ分布を計測するための検査領域の重複と階層 化, および各時刻における物質点の追跡と変位ベクト ルの更新の手順について示す. 第 3 章では, モルタル供 試体とコンクリート供試体の圧縮試験に, 本研究で構 築した画像相関法に基づく画像解析手法を適用し，そ の結果について比較・検討する．まず，ひずみゲージ による計測結果との比較を行い, 本研究で構築した画 像解析の精度を検証する. 次に, モルタル供試体の圧 縮試験を対象に，第 2 章で示した画像相関法に関する 比較を行い, 目視で確認できない微小なひび割れから, 巨視的なひび割れまでを計測するための方法を検討す る. 最後に, コンクリート供試体の圧縮試験を対象に, 粗骨材の影響による複雑なひび割れ進展挙動の再現性 について検討する. 第 4 章では, 本研究の総括を行い, 今後の展望について述べる.

\section{2. 画像相関法による变形計測}

本章では, 本研究で構築した画像相関法に基づく画 像解析手法について説明する. 高解像度のグリッドで

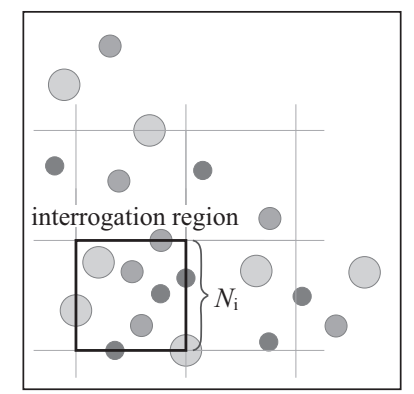

Image 1 (before deformation)

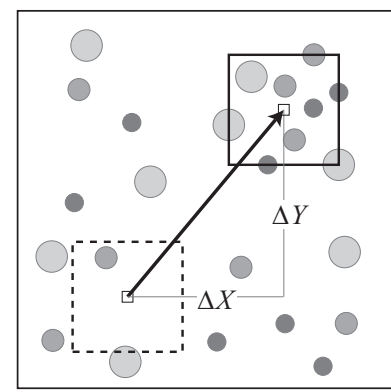

Image 2 (after deformation)
図-1 画像相関法の概要

ひずみ分布を計測するための検査領域の重複と階層化， および各時刻における物質点の追跡と変位ベクトルの 更新の手順について示す.

\section{(1) PIV における画像相関法}

トレーサと呼ばれるマーカーを挿入した流れ場のデ ジタル画像から, 流れ場の瞬時・多点の流速ベクトル を測定する方法を PIV（Particle Image Velocimetry）と いう. PIV 解析手法は, 輝度值パターンを追跡する画像 相関法と, 個々の粒子を追跡する粒子追跡法に大別さ れる.

画像相関法は, 図-1に示すように, 画像を検査領域 と呼ばれる小領域に分割し, 異なる 2 時刻の画像の間 で, 領域内の輝度值パターンが類似している領域を探 查することにより, 領域内の平均移動量を算出する方 法である ${ }^{4)}$. 第一画像を変形前, 第二画像を変形後と すれば，準静的な問題の変位ベクトルを求めることが できる，画像は, 中間輝度レベルを多く有する濃淡画 像であり, 比較的粒子数密度の高いものを利用する.

主な画像相関法として, 直接相互相関法と FFT 相互 相関法がある. FFT 相互相関法は, 輝度值パターンの 周期性を仮定し, FFT を利用して相互相関を求める方 法である. 解析に必要なパラメータは検査領域サイズ $N_{\mathrm{i}}$ のみであり, 非常に簡便な方法ではあるが, 移動量 が大きくなるほど, 輝度值パターンの周期性が保証さ れず，測定精度が低下するといった問題がある．一方， 直接相互相関法は, FFT 相互相関法と比較して, 計算 量やパラメータは多くなるが, 輝度值パターンの周期 性を仮定しないため, 測定精度の点で有利である. 本 研究では, 簡便性よりも測定精度に着目し, 画像相関 法のうちの直接相互相関法を採用する.

\section{(2) 直接相互相関法}

図-2 は, 直接相互相関法において, 輝度值パターン の移動量を検出する方法の概略を示している. 最初に, 第一画像における任意の位置 $\mathrm{A}$ を中心とする $N_{\mathrm{i}} \times N_{\mathrm{i}}$ の 


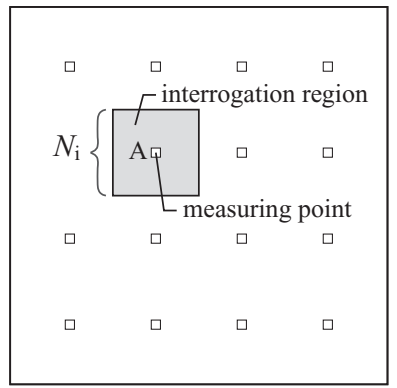

Image 1 (before deformation)

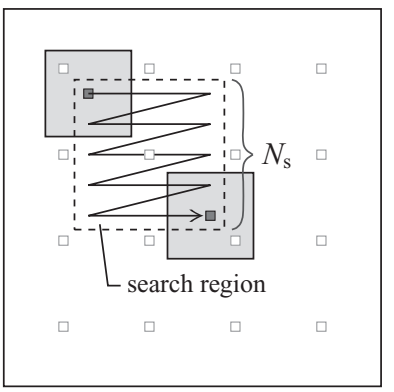

Image 2 (after deformation)

図-2 直接相互相関法による移動量ベクトルの検出方法

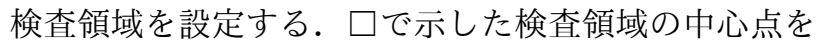
測定点と呼ぶ。次に，第二画像において，位置 $\mathrm{A}$ を中 心とする $N_{\mathrm{s}} \times N_{\mathrm{s}}$ の探査領域を設ける．探査領域の中か ら, 第一画像で設定した検査領域の輝度值パターンと 最も類似した領域を特定する.

直接相互相関法では，第一画像における検査領域の 輝度值パターンが，第二画像における探査領域のどの 位置に移動したかを相互相関関数を用いて評価する. 本 研究で使用する相互相関関数 $R_{f g}(\Delta X, \Delta Y)$ は, 次式で表 される.

$$
\begin{aligned}
& R_{f g}(\Delta X, \Delta Y) \\
& =\frac{\sum_{i=1}^{N_{i}} \sum_{j=1}^{N_{i}} f\left(X_{i}, Y_{j}\right) g\left(X_{i}+\Delta X, Y_{j}+\Delta Y\right)}{\sqrt{\sum_{i=1}^{N_{i}} \sum_{j=1}^{N_{i}} f\left(X_{i}, Y_{j}\right)^{2} \sum_{i=1}^{N_{i}} \sum_{j=1}^{N_{i}} g\left(X_{i}+\Delta X, Y_{j}+\Delta Y\right)^{2}}}
\end{aligned}
$$

ここで, $\Delta X$ は $X$ 方向の移動量, $\Delta Y$ は $Y$ 方向の移動量, $f(X, Y)$ は第一画像の輝度值関数, $g(X, Y)$ は第二画像の 輝度值関数である. 第二画像の探査領域内において, 相 互相関関数 $R_{f g}(\Delta X, \Delta Y)$ の分布を求め, $R_{f g}(\Delta X, \Delta Y)$ の ピーク值となる $(\Delta X, \Delta Y)$ が第一画像における検査領域 の平均移動量となる.

\section{(3) 測定グリッド（検查領域の配置）}

画像相関法によって得られる移動量ベクトルは, 第一 画像における検査領域の測定点 (中心位置) での平均移 動量である. 通常, 測定点は正方格子状に設定される. 重複や隙間を作らずに検査領域を並べると, 図-3 (a) に 示すような正方形状の測定グリッドができる．この場 合，測定グリッドの要素サイズは検査領域と同じにな る. 検查領域を小さくすれば，より高解像度の測定グ リッドとなるが，検査領域を小さくすると，輝度值パ ターンの個性がなくなることにより, 誤った変位べク トルが検出される可能性が高くなる.

画像相関法を用いて，ひび割れの形成・進展を捉える には，可能な限り測定グリッドは細かい方が望ましい。

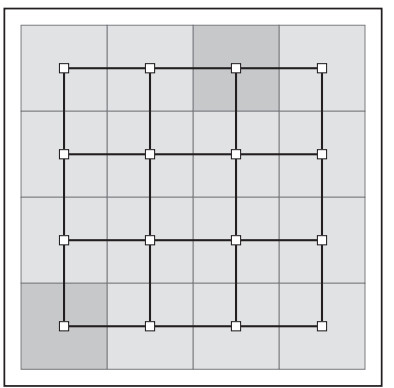

(a) pivfem

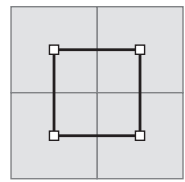

(c) Illustration of an element composed of 4 interrogation regions

図-3 pivfem と pivfcm による測定グリッドの相違

しかし，検査領域を小さくすると，画像相関法の精度 が低下する. 図-3 (b) は, 検査領域を半領域オーバー ラップさせて，測定グリッドを作成する方法を示して いる.これにより, 検査領域の輝度值パターンの独立 性は低下するものの, 検査領域を小さくすることなく, 測定グリッドの解像度を高くすることができる.

図-3 (c) は，測定グリッドにおける要素（測定セル） の構成を図解したものである。本論文では, 検査領域 を重複させずに測定グリッドを作成する方法を pivfem, 検査領域を重複させて測定グリッドを作成する方法を pivfcm と便宜上呼ぶこととする.

\section{（4）検査領域の階層化}

画像相関法では，検査領域を小さくすると，測定グ リッドの解像度が高くなり, 詳細な変形を計測・可視化 することができる．しかし，検査領域を小さくすると， 測定グリッドは高解像度になるが，輝度值パターンの 個性がなくなり, 誤った変位ベクトルを検出する可能 性が高くなる. 逆に, 検査領域を大きくすると, 測定精 度は高くなるが，測定グリッドの解像度が下がる。こ のように，画像相関法において，検査領域サイズと測 定グリッドサイズの関係はトレードオフの関係にある.

検査領域と測定グリッドのトレードオフの関係を改 善するために, 本研究では, 図-4に示すような検査領 域の階層化手法を取り入れる。階層化とは，検査領域 を段階的に小さくしていくことである.はじめに，大 きな検査領域で大まかな移動量べクトルを求めておく. 次に, 検査領域を小さくして, 詳細な移動量ベクトル を求める.これにより, 検査領域を小さくして, 測定 


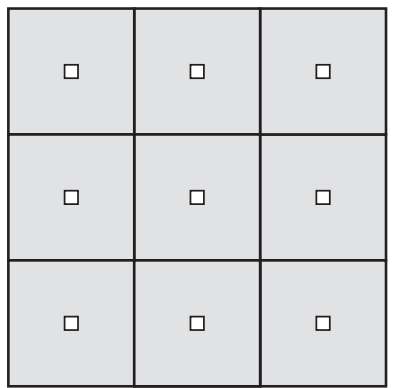

Level-0

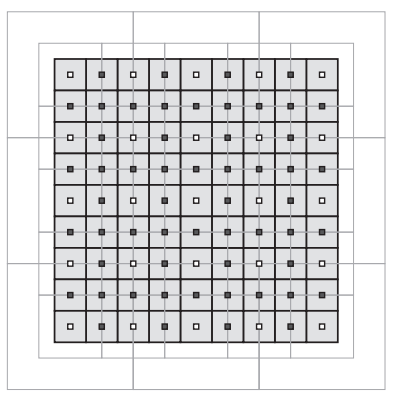

Level-2

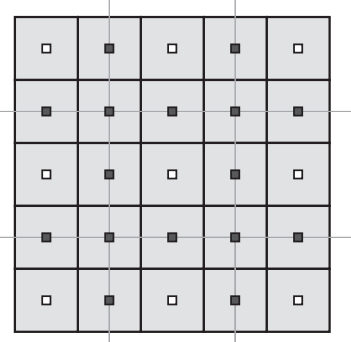

Level-1

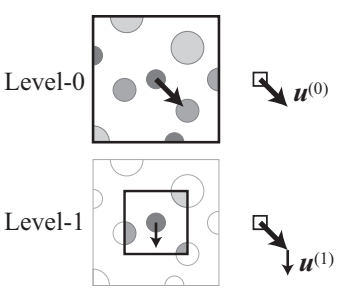

Level-2
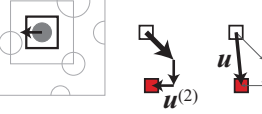

図-4 検査領域の階層化による変位ベクトルの計算方法

グリッドを高解像度にしても, 誤った変位ベクトルを 検出する可能性が低くなる.

図-4 は, pivfem に対して, 階層化を 2 回行い, 移動 量ベクトル $\boldsymbol{u}$ を求める例である. はじめに, 階層化を 行う前の Level-0 の $3 \times 3$ の測定点において，大まかな 移動量ベクトル $\boldsymbol{u}^{(0)}$ を求める. 次に, 階層化を一回行 い, Level-1 の $5 \times 5$ の測定点において, Level-0 で求め た $\boldsymbol{u}^{(0)}$ を考慮した状態，つまり大まかな移動量 $\boldsymbol{u}^{(0)}$ を 変位させた状態で, より詳細な移動量ベクトル $\boldsymbol{u}^{(1)}$ 求める.このとき, Level-1 において, Level-0の $\boldsymbol{u}^{(0)}$ が 存在しない口の測定点では, $\boldsymbol{u}^{(0)}$ が得られている上下左 右の $\square$ の測定点の值を用いて一次補間で近似する．同 様に, Level-2 の $9 \times 9$ の測定点において, 移動量べク トル $\boldsymbol{u}^{(2)}$ を求めることにより, 最終的な移動量ベクト ル $\boldsymbol{u}$ は $\boldsymbol{u}=\boldsymbol{u}^{(0)}+\boldsymbol{u}^{(1)}+\boldsymbol{u}^{(2)}$ となる.

\section{(5) 物質点の追跡と変位ベクトルの更新}

計測対象にひび割れの発生・進展があると, 不連続 面の形成や応力の再分配により, 画像の乱れや大きな 変位を生じる可能性がある. 本研究では, 時刻の進行 毎に変位場を求め, 初期の測定点 (物質点) を追跡し て，変位ベクトルを更新する方法を取り入れる.

図-5 は, 時刻 $t=t_{0}$ から $t=t_{3}$ に対して, 初期の測 定点（物質点）A の変位ベクトルを求める手順を示し た例である.まず，時刻 $t_{0}$ から $t_{1}$ において，変位場を 求めると図-5 (a) のようになり, 物質点 A は同図 (b) の 位置に移動する．次に, 時刻 $t_{1}$ から $t_{2}$ において変位場

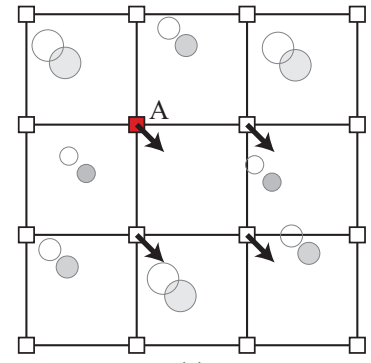

(a)

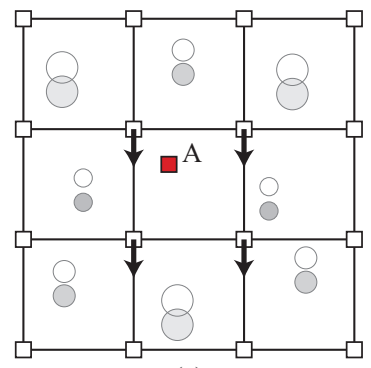

(c)

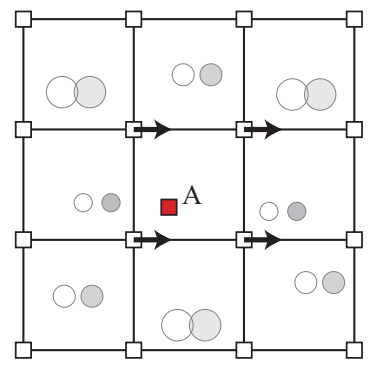

(e)

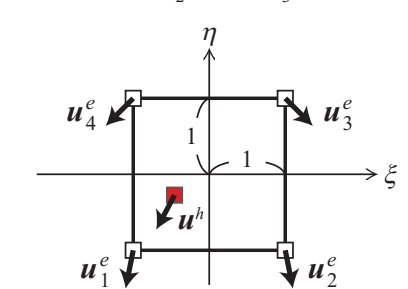

(g) Interpolation of displacement in natural coordinate

図-5 物質点 $\mathrm{A}$ の追跡と補間近似による変位ベクトルの更新

を求めると, 図-5 (c) のようになる. このとき, 画像を 撮影するカメラは固定されているので, 時刻 $t_{1}$ の画像 において作成される測定グリッドは $\mathrm{A}$ 点とは一致しな い. 本研究では, A 点を含む要素の変位場から, 四角 形有限要素の形状関数を用いて, 双一次補間により $\mathrm{A}$ 点の変位ベクトルを求める. 要素 $e$ における節点変位 ベクトルを $\boldsymbol{u}_{I}^{e}$ とすると, 自然座標系 $(\xi, \eta)$ における変 位ベクトル $\boldsymbol{u}^{h}$ は次式で表される。

$$
\boldsymbol{u}^{h}(\xi, \eta)=\sum_{I=1}^{4} N_{I}^{e}(\xi, \eta) \boldsymbol{u}_{I}^{e}
$$

ここで, $N_{I}^{e}$ は形状関数であり, 次式で与えられる. 


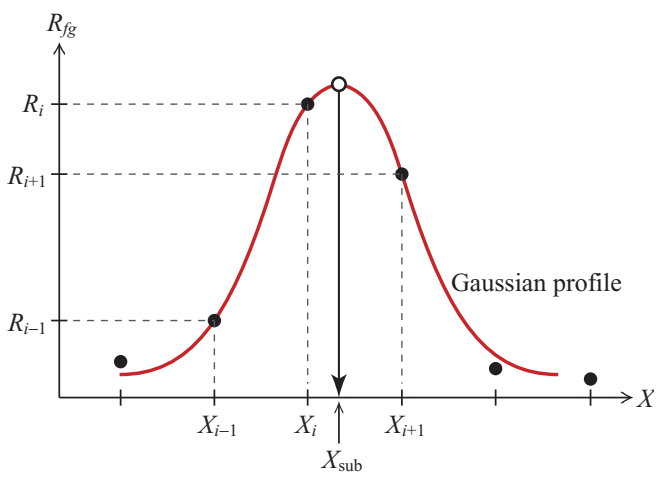

図-6 ガウス分布によるサブピクセル推定

$$
\left.\begin{array}{rl}
N_{1}^{e}(\xi, \eta) & =\frac{1}{4}(1-\xi)(1-\eta) \\
N_{2}^{e}(\xi, \eta) & =\frac{1}{4}(1+\xi)(1-\eta) \\
N_{3}^{e}(\xi, \eta) & =\frac{1}{4}(1+\xi)(1+\eta) \\
N_{4}^{e}(\xi, \eta) & =\frac{1}{4}(1-\xi)(1+\eta)
\end{array}\right\}
$$

これより, 時刻 $t_{2}$ において, 測定点 $\mathrm{A}$ は同図 (d) の位 置に移動する. 同様に, 時刻 $t_{2}$ から $t_{3}$ においては, 図一 5 (e) のように測定グリッドが作成され, 物質点 $\mathrm{A}$ は同 図 (f) の位置に移動する. 以上のように, 時刻毎に変位 場を求め, 初期の測定点（物質点）を追跡して, 変位 ベクトルを更新していく.

\section{(6) サブピクセル解析}

デジタル画像上で輝度值パターンの移動を単純に追 いかけると, 整数画素単位の移動量しか求まらない. 本 研究では, 0.1 pixel の精度で輝度值パターンの移動量 を測定するために, 関数近似による簡易なサブピクセ ル解析を導入する. 図-6に示すように, 相互相関值が 最大となる位置 $X_{i}$ とその両隣の位置 $X_{i-1}, X_{i+1}$ に対し て, ガウス分布を仮定することにより，相互相関が極 大值となる位置 $X_{\text {sub }}$ を次式で近似することができる.

$$
X_{\text {sub }}=X_{i}-\frac{1}{2} \frac{\ln R_{i+1}-\ln R_{i-1}}{\ln R_{i+1}-2 \ln R_{i}+\ln R_{i-1}}
$$

ここで, $R_{i}, R_{i-1}, R_{i+1}$ はそれぞれ位置 $X_{i}, X_{i-1}, X_{i+1}$ に おける相互相関值である.

\section{(7) ひずみの算出}

画像相関法において正方形の検査領域を設けること により，最終的に正方形状の測定グリッドで変位ベク トルが求まる. 本研究では, 測定された変位ベクトル からひずみを求めるに際し, 次式で表される四角形有 限要素の変位一ひずみ関係式を用いて, 各要素の中心 点でのひずみを算出する.
表-1 モルタルの配合

\begin{tabular}{c|c}
\hline \hline 水セメント比 $(\%)$ & 55 \\
\hline 空気量 $(\%)$ & 5 \\
\hline 単位水量 $\left(\mathrm{kg} / \mathrm{m}^{3}\right)$ & 284 \\
\hline 単位セメント量 $\left(\mathrm{kg} / \mathrm{m}^{3}\right)$ & 516 \\
\hline 単位細骨材量 $\left(\mathrm{kg} / \mathrm{m}^{3}\right)$ & 1295 \\
\hline \hline
\end{tabular}

表-2 コンクリートの配合

\begin{tabular}{c|c}
\hline \hline 水セメント比 $(\%)$ & 55 \\
\hline 空気量 $(\%)$ & 5 \\
\hline 単位水量 $\left(\mathrm{kg} / \mathrm{m}^{3}\right)$ & 182 \\
\hline 単位セメント量 $\left(\mathrm{kg} / \mathrm{m}^{3}\right)$ & 330 \\
\hline 単位細骨材量 $\left(\mathrm{kg} / \mathrm{m}^{3}\right)$ & 684 \\
\hline 単位粗骨材量 $\left(\mathrm{kg} / \mathrm{m}^{3}\right)$ & 1010 \\
\hline \hline
\end{tabular}

$$
\boldsymbol{\varepsilon}^{e}=\boldsymbol{B}^{e} \boldsymbol{u}^{e}
$$

ここで, $\boldsymbol{\varepsilon}^{e}, \boldsymbol{B}^{e}, \boldsymbol{u}^{e}$ はそれぞれ次式で与えられる.

$$
\begin{aligned}
\boldsymbol{\varepsilon}^{e} & =\left\{\begin{array}{lllllllll}
\varepsilon_{x} & \varepsilon_{y} & \gamma_{x y}
\end{array}\right\}^{T} \\
\boldsymbol{B}^{e} & =\frac{1}{4}\left[\begin{array}{ccccccccc}
-1 & 0 & 1 & 0 & 1 & 0 & -1 & 0 \\
0 & -1 & 0 & -1 & 0 & 1 & 0 & 1 \\
-1 & -1 & -1 & 1 & 1 & 1 & 1 & -1
\end{array}\right] \\
\boldsymbol{u}^{e} & =\left\{\begin{array}{llllllll}
u_{1}^{x} & u_{1}^{y} & u_{2}^{x} & u_{2}^{y} & u_{3}^{x} & u_{3}^{y} & u_{4}^{x} & u_{4}^{y}
\end{array}\right\}^{T}
\end{aligned}
$$

\section{3.ひび割れ進展計測の比較・検討}

本章では，モルタル供試体とコンクリート供試体の 圧縮試験を対象に, 前章で示した画像解析手法を適用 し，その結果について比較・検討する.まず，ひずみ ゲージによる計測結果との比較を行い, 本研究で構築 した画像解析手法の妥当性を示す. 次に, モルタル供 試体の圧縮試験を対象に, 前章で示した画像相関法に 関する比較を行い, 目視できない微小なひび割れから 巨視的なひび割れまでを計測するための方法を検討す る. 最後に, コンクリート供試体の圧縮試験への応用 例を示し, 粗骨材の影響による複雑なひび割れ進展挙 動に対する適用性や有効性を検討する.

\section{(1) 供試体の概要}

本研究では, モルタル供試体およびコンクリート供 試体の圧縮試験を行った。供試体の作製に使用したモ ルタルの配合を表-1に，コンクリートの配合を表-2に 示す.コンクリートに含まれる粗骨材（砕石）の最大寸 法は $15 \mathrm{~mm}$ である. 本研究における圧縮試験は, 画像 


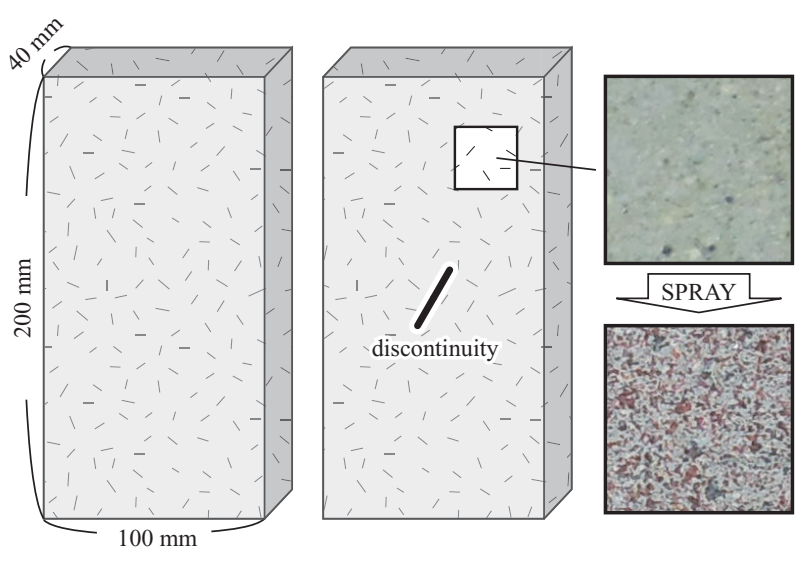

図-7 供試体の概要と供試体表面の詳細

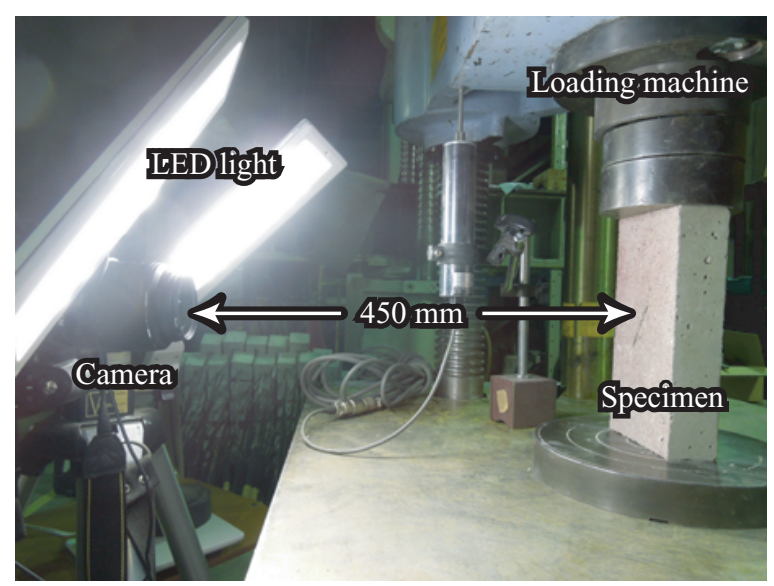

図-8 圧縮試験と撮影の様子

解析手法の検証のための実験という位置づけから，ひ び割れを徐々に進展させるために，水セメント比を若 干高くしている.

作製した供試体の寸法を図-7に示す。モルタル供試 体とコンクリート供試体は同寸法で作製した. 2 次元的 なひび割れを発生させるために，横幅に対して奥行き を半分以下とした，モルタル供試体は，不連続面を持 つものと持たないものを作製し，コンクリート供試体 は不連続面を持つもののみ作製した。供試体はすべて, 型枠に材料を流し込んでから 24 時間後に脱型し, 気中 養生で 7 日間養生した。

画像解析時に誤差を生じにくくするために，試験を 行う前に, 撮影面にスプレー塗料を塗布して, 供試体 表面の模様（輝度值パターン）のランダム性を強めた。 スプレーには，赤と黒のアクリルスプレーを使用した。 図-7に，スプレー塗料を塗布する前後の供試体表面の 一部を示す．ひずみの精度を検証するために，不連続 面を持たない供試体のみ，供試体の裏面にひずみゲー ジを貼付した.

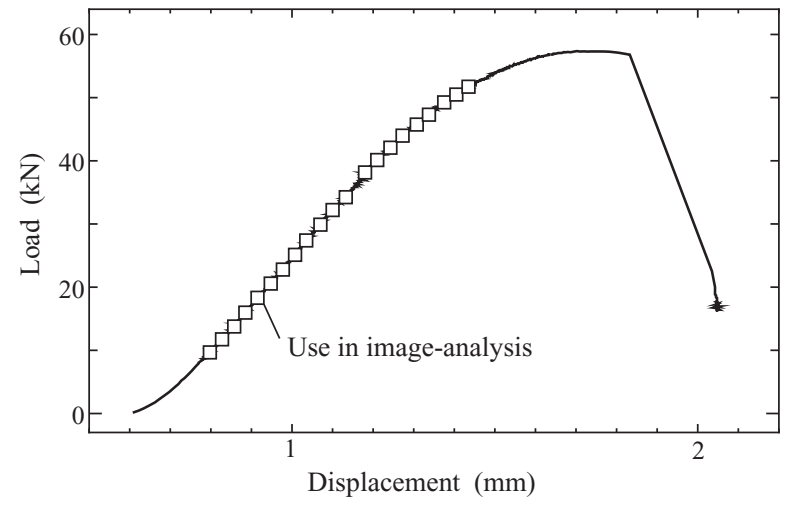

図-9 不連続面を持たないモルタル供試体の荷重一変位関係

\section{(2) 圧縮試験と撮影の条件}

図-8に，圧縮試験と撮影の様子を示す．撮影の様子 を見やすくするために，図中のカメラは横に設置され ているが, 縦長の供試体を撮影する際には, カメラを 縦に設置して撮影を行う. 試験の載荷速度は $3 \mathrm{kN} / \mathrm{min}$ とし，見かけの垂直ひずみを算出するために，供試体 上面の鉛直変位を計測した。また，不連続面を持たな い供試体のみ，ひずみゲージによって垂直ひずみを計 測した。

供試体の撮影には, Nikon D3100 のデジタル一眼レフ カメラを使用した。画素数は, 約 1400 万画素 $(4608 \times$ 3072）である.レンズには, 焦点距離 18-55 mm のズー ムレンズを使用し，可能な限り供試体のみが撮影され るようにした。画像相関法による変形計測は画像の明 度を基に行うため, すべての画像が一定の明るさで撮 影される必要がある.そのため, 照明には, 光のちらつ きがほとんどない LED 照明を用いた。より明度を一定 に保つために，照明を 2 つ用意し，カメラの左右から 均等に照射するように設置した。試験は，LED 照明以 外の光源の影響をなくすために, 実験室の照明をすべ て切った上で行った. カメラと供試体の距離は $450 \mathrm{~mm}$ とした。撮影間隔は 2 秒に 1 回とし, 載荷前から供試 体が破壊するまで撮影を行った，画像の明るさは，撮影 時の F 值，シャッタースピード，ISO 感度という 3 つの パラメータに依存しており, 本研究ではこれらを F36, $1 / 10$ 秒， 3200 として撮影を行った。

\section{(3) ひずみの精度検証}

不連続面を持たないモルタル供試体の圧縮試験を対 象に, 画像解析で得られるひずみの精度検証を行う. 第 2 章で示した方法のうち，ここでは検査領域を重複させ て配置する pivfcm（図-3 参照）を適用する。画像解析 に使用する画像のサイズを $4068 \times 2022$ pixel とし, 撮 影したデジタル画像のうち 21 枚を使用した. 


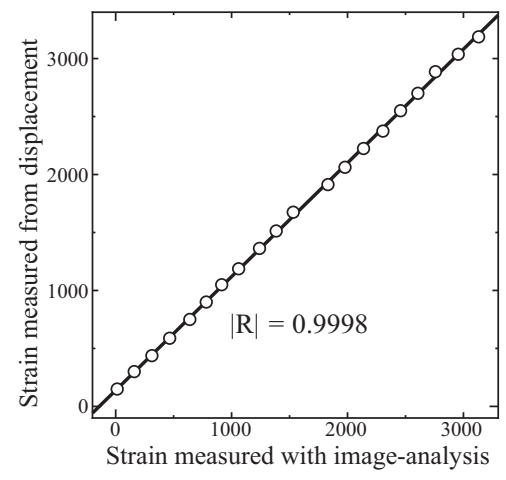

(a) Image-analysis versus overall strain

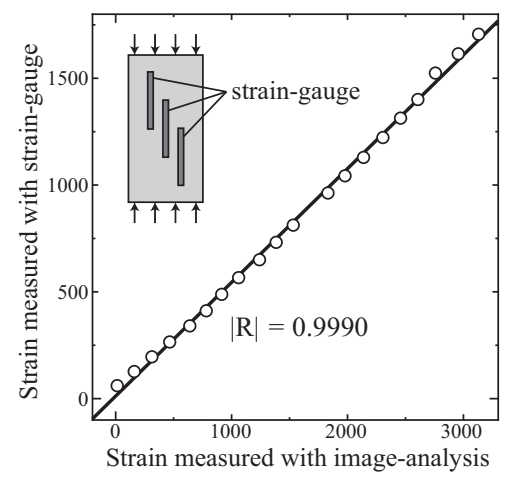

(b) Image-analysis versus strain-gauge

図-10 画像解析によるひずみの精度検証の結果

図-9に, 荷重一変位関係を示す．図中の $\square$ は, 画像 解析を実施した箇所を示している．鉛直変位から求め た見かけのひずみと画像解析から求めたひずみとの相 関を図-10 (a)に，ひずみゲージから得たひずみと画像 解析から求めたひずみとの相関を図-10 (b)に示す。 ひ ずみゲージは，図-10 (b)に示すように，供試体の対角 上に 3 箇所貼付し，ひずみの值は 3 つの平均值とする. 横軸の画像解析から求めたひずみは, 撮影面全域のひ ずみの平均值である．それぞれのひずみの関係を見る と，非常に強い相関が確認できる。このことから，本 研究で実施した画像相関法による変形計測は妥当であ るとともに，その精度は非常に高いことが分かる.

\section{（4）モルタル供試体のひび割れ進展計測}

不連続面を持つモルタル供試体の圧縮試験を対象に, 本研究で構築した画像解析によるひび割れ進展計測に ついて比較・検討する.

図-11に，不連続面を持つモルタル供試体の圧縮試験 の荷重一変位関係を示す.モルタル供試体の画像サイズ を 3954×1980 pixel とし，撮影した全画像のうち，図中 の $\square$ で示した箇所の 11 枚を使用した。第 2 章で示した 方法のうち，ここでは検査領域の取り方の異なる pivfem と pivfcm（図-3 参照），および階層化の有無（図-4参 照）による 4 ケースについて比較・検討する．作成さ

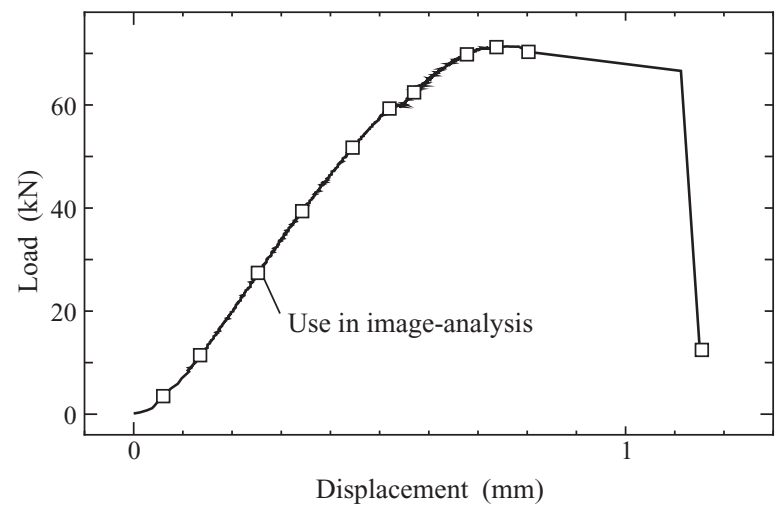

図-11 不連続面を持つモルタル供試体の荷重一変位関係

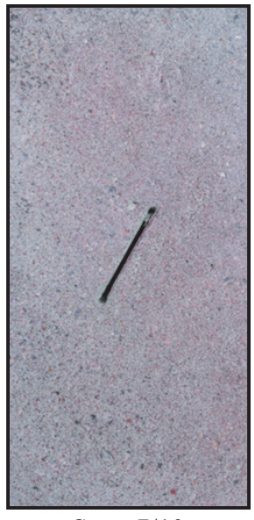

Step: $7 / 10$

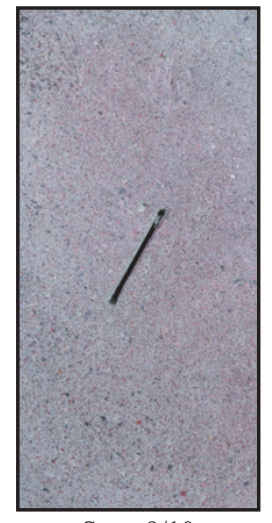

Step: $9 / 10$

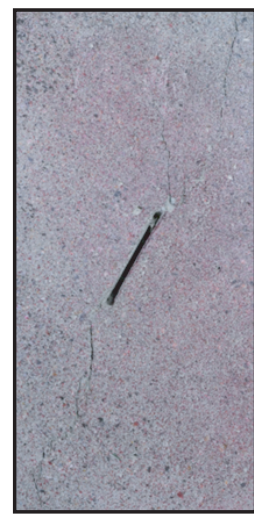

Step: $10 / 10$
図-12 圧縮試験中におけるモルタル供試体の実際の画像

れる測定グリッドの解像度が，すべてのケースでほぼ 同じになるよう設定した．本節では，4 ケースを以下の ように定義する．すべてのケースにおいて，探査領域 は $35 \times 35$ とする.

・ pivfem-0 : 検査領域を重複させずに配置する pivfem とし，階層化は行わない，検査領域を $20 \times 20$ とし， 作成される測定グリッドは $95 \times 193$ となる.

- pivfcm-0 : 検査領域を重複させて配置する pivfcm とし, 階層化は行わない. 検査領域を $40 \times 40$ とし, 作成される測定グリッドは $96 \times 194$ となる.

- pivfem-2：pivfem に対して階層化を 2 回行う。初 期の検査領域を $72 \times 72$ とし, 最終的に作成される 測定グリッドは $100 \times 208$ となる.

- pivfcm-2 : pivfcm に対して階層化を 2 回行う。初 期の検査領域を $140 \times 140$ とし, 最終的に作成され る測定グリッドは $100 \times 208$ となる.

図-12 は，圧縮試験中における供試体の実際の画像で ある. 以下では, この 3 ステップに対して，4 ケースの 画像解析結果について比較・検討する. 画像解析の結 果を可視化するにあたり，次式で表されるひずみノル ムを採用した。 


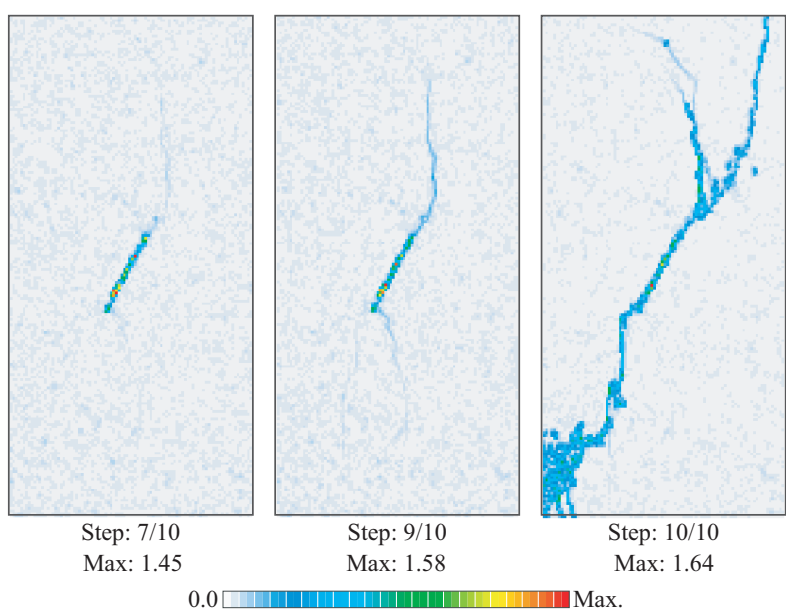

(a) Distribution of strain norm in case of pivfem-0

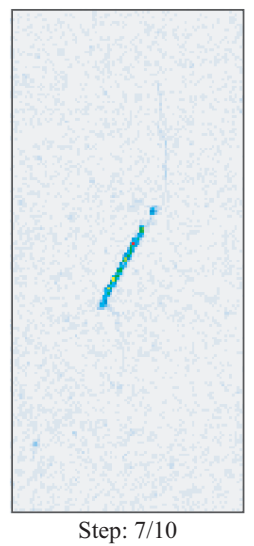

Max: 1.64

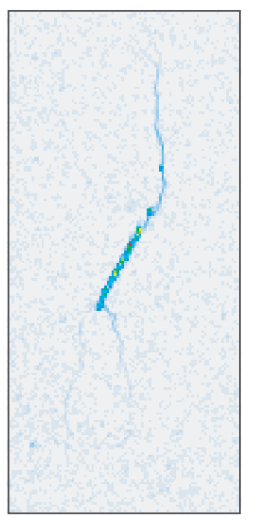

Step: $9 / 10$

Max: 2.54

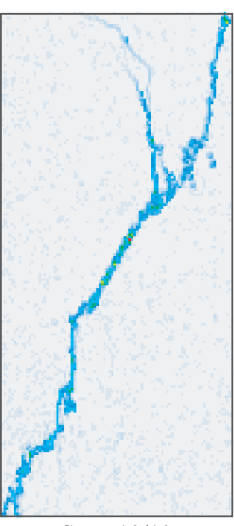

Step: $10 / 1$ Max: 3.28

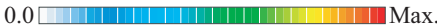

(b) Distribution of strain norm in case of pivfem-2

図-13 pivfem によるモルタル供試体の画像解析結果

$$
|\boldsymbol{\varepsilon}|=\sqrt{\varepsilon_{x}^{2}+\varepsilon_{y}^{2}+\gamma_{x y}^{2}}
$$

予備検討において, 主ひずみや最大せん断ひずみなど, 他のひずみを可視化しても，ほぼ同様のコンター図に なることを確認している.

本研究の画像解析で得られるひずみは, 矩形要素中 の平均ひずみとなる，要素内が固体のみの場合は，ひ ずみの精度検証で示したように，非常に高精度なひず みの值が計測される。しかし, 初期不連続面や発生し たひび割れを要素内に含む場合, それらを含んだ要素 の平均ひずみになるため, 計測されるひずみ值の物理 的意味は希薄となる.

はじめに, pivfem-0 と pivfem-2 の画像解析結果を図13 に示す. 7/10 ステップ目の実際の画像と画像解析の 結果を比較すると, 実際の画像では目視でひび割れを 判別できないが, 画像解析の結果ではひび割れが見え 始めていることが分かる.さらに，9/10 ステップ目で は，実際の画像ではまだひび割れが見えないが，画像

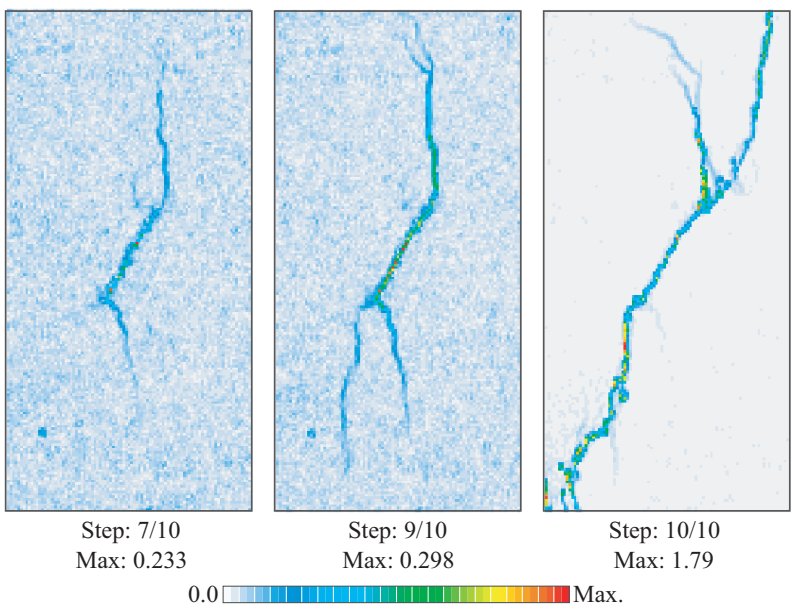

(a) Distribution of strain norm in case of pivfem- 0

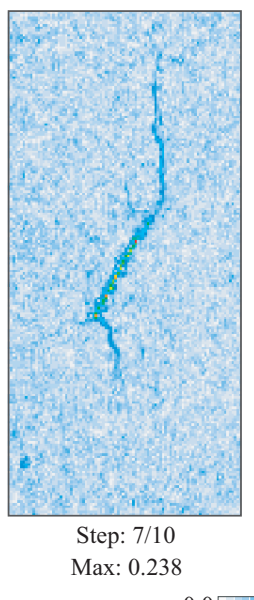

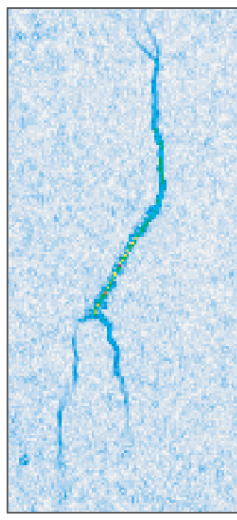

Step: $9 / 10$ Max: 0.415

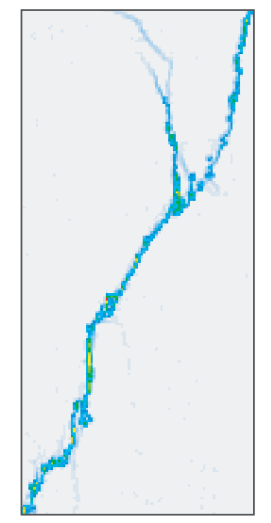

Step: $10 / 10$ Max: 2.68 (b) Distribution of strain norm in case of pivfem-2

図-14 pivfcmによるモルタル供試体の画像解析結果

解析の結果では，ひび割れがよりはっきりと見えてい る. 最終ステップでは, 実際の画像に見えているひび 割れと, 画像解析の結果が一致していることが確認で きる. 以上の結果は, 階層化の有無によらず同様の傾 向を示している.

pivfem-0 の 10/10 ステップ目の結果を見ると, 左下の 部分に測定誤差の集積が見られる。ひび割れの進展に よって, 画像の乱れや大きな変位が生じたために, 相関 が適切に評価されず, 䛊った変位ベクトルが検出された と考えられる.しかし，階層化を 2 回行った pivfem-2 の結果の同じ箇所を見ると, 誤差の集積は見られない. 階層化の効果により, 誤った変位ベクトルの検出が回 避されたことが確認できる。

次に, pivfcm-0 と pivfcm-2 の画像解析結果を図-14に 示す. 前に示した pivfem の結果と比較して, pivfcm で は検査領域を重複させることにより，ひずみ分布の乱 れが若干見られている.しかし, pivfemの結果と比較 すると，7/10 ステップ目と 9/10 ステップ目において， 


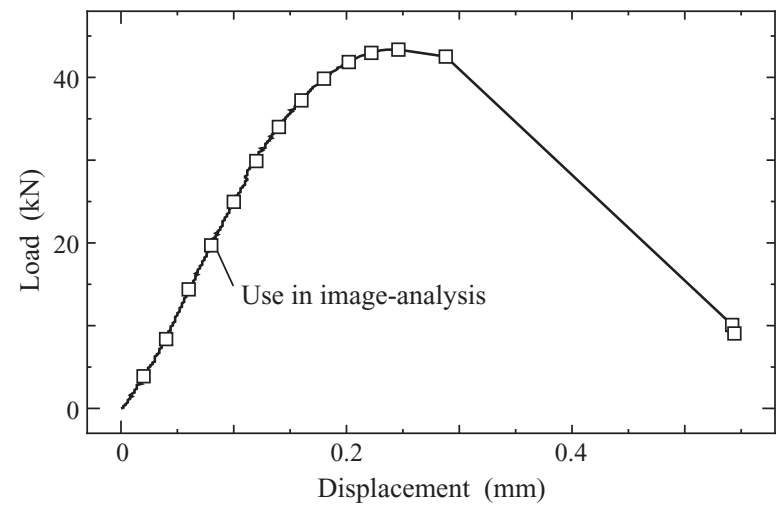

図-15 不連続面を持つコンクリート供試体の荷重－変位関係

実際の画像では確認できない微小なひび割れが，階層 化の有無によらず非常に明確に計測されていることが 分かる. また, 9/10 ステップ目において, 不連続面の 下部に 2 本の微小なひび割れが生じているが，10/10 ス テップ目ではそのひび割れが 1 本になっている。これ は, ひび割れ進展に伴う応力の再分配によって, 右側 のひび割れが閉じ，左側のひび割れに局所化したこと を意味しており, 本手法は応力の再分配によるひび割 れの閉口をも計測可能であることを示している. 以上 の結果より, 検査領域を重複させると, ひずみ分布に 若干の誤差が生じるものの, pivfem よりも pivfcm の方 がひび割れの検出や可視化に有効であると考えられる.

\section{(5) コンクリート供試体のひび割れ進展計測}

不連続面を持つコンクリート供試体の圧縮試験を対 象に, 本研究で構築した画像解析によるひび割れ進展 計測の有効性について検討する.

図-15に，コンクリート供試体の圧縮試験の荷重一 変位関係を示す。コンクリート供試体の画像サイズを $4208 \times 2184$ pixel とし, 撮影した全画像のうち, 図中の 口で示した箇所の 15 枚を使用した. 用いる画像解析手 法は, モルタル供試体のひび割れ進展計測において有 効性が示された pivfcm とし, 階層化を 2 回行うことと する. 画像解析における探査領域を $35 \times 35$, 初期の検 查領域を $40 \times 40$ とし, 最終的に作成される測定グリッ ドは $112 \times 224$ となる.

12/14, 13/14, 14/14 ステップ目における実際の供試体 の画像と画像解析の結果を図-16に示す.モルタル供試 体の結果と同様に, 目視では確認が困難な微小なひび 割れを画像解析で捉えられていることが確認できる.さ らに，コンクリートに含まれる粗骨材の影響によって， ひび割れが粗骨材を迂回して進展するような挙動が見 られ, モルタルの結果よりも複雑なひび割れ進展挙動 が再現できている. 最終的な破壊面の形成後において,

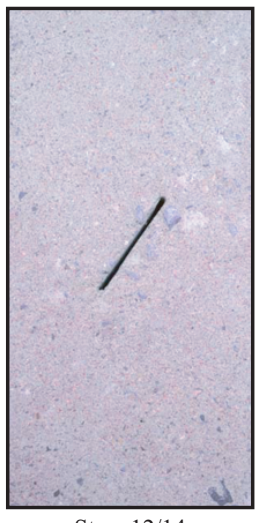

Step: $12 / 14$

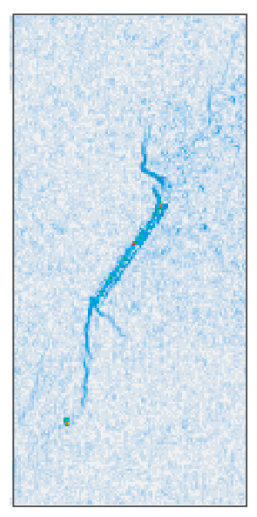

Step: $12 / 14$

Max: 0.673

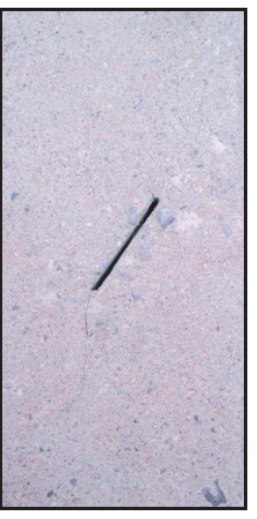

Step: $13 / 14$

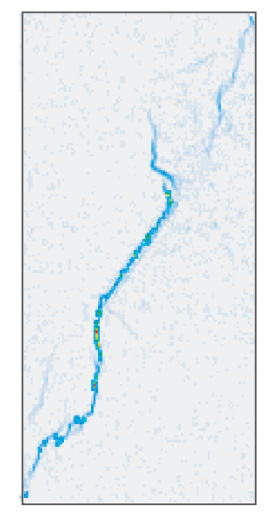

Step: $13 / 14$

Max: 1.96

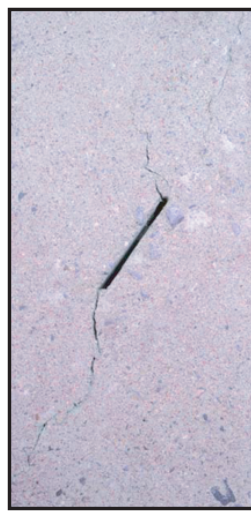

Step: $14 / 14$

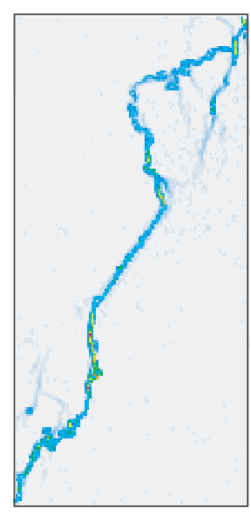

Step: $14 / 14$

Max: 3.04
図-16 pivfcm によるコンクリート供試体の画像解析結果

実際のひび割れ発生箇所と画像解析の結果は一致して いることが分かる. 以上のことから, 本研究で構築し た画像解析によるひび割れ進展計測は, 粗骨材を含む コンクリートの微小な変形や複雑なひび割れ進展挙動 にも適用可能である.

\section{4. おわりに}

コンクリートに発生するひび割れは, 部材の力学性 能や耐久性を低下させることから，損傷の過程を評価・ 予測する方法が必要とされている，しかし，目視でき ない微細なひび割れを計測するのは容易ではなく，ま た計測の困難性から破壊シミュレーションによる予測 も研究途上である.コンクリートのひび割れ進展挙動 を計測・可視化することができれば，損傷の判別や破 壊機構の解明が可能になる. 破壊シミュレーションを 高度化させるためにも, 複雑なひび割れ進展挙動を計 測・可視化する技術が必要である.

本論文では，画像相関法における検査領域の重複や 階層化, 物質点の追跡と変位ベクトルの更新を実装し た画像解析手法を構築し，コンクリートのひび割れ進 展挙動の計測・可視化について検討した. はじめに，モ 
ルタル供試体の圧縮試験を対象に，ひずみの精度検証 を行った後, pivfem と pivfcm, および階層化の有無に 関して比較・検討した。その結果，階層化によって画像 相関法における誤差の発生を抑えられることに加えて, 検査領域を重複させて測定グリッドを高解像度にした 方が，微細なひび割れ進展挙動の計測に有効であるこ とを例示した。さらに，粗骨材を含むコンクリート供 試体の圧縮試験に本研究で構築した画像解析を応用し た結果，粗骨材の影響による複雑なひび割れ進展挙動 の計測にも適用可能であることを示した.

本論文において，供試体レベルでひび割れ進展挙動 の計測・可視化が行えることを示した．今後は，本研究 の成果を, 破壊シミュレーションの妥当性検証 $(\mathrm{V} \& \mathrm{~V})$ に応用させ，数值解析による予測の高度化に役立てる とともに, 部材レベルでひび割れ進展挙動の計測・可 視化が行えるかどうかを検討する予定である.

謝辞：本研究は, 平成 22 年度科学研究費補助金（基 盤研究 $(\mathrm{B})$ ：23360188）の援助を得て行われました。ま た，木更津工業高等専門学校の石井建樹先生, 電力中 央研究所の石丸 真氏には, 画像解析や試験方法に関す るご助言を頂きました。

\section{参考文献}

1) 応用力学委員会 計算力学小委員会 : 土木工学における計 算力学手法の研究動向, 土木学会論文集 A2 (応用力学), Vol.68, No.1, pp.31-50, 2012.
2) 白鳥正樹, 越塚誠一, 吉田有一郎, 中村均, 堀田亮年, 高野直樹 : 工学シミュレーションの品質保証と V\&V, 丸 善出版, 2013.

3) 松田 浩, 神原天鳴, 才本明秀, 阪上直美, 山下 務, 崎 山 毅 : スペックル干渉による非接触全視野ひずみ計測法, 応用力学論文集, Vol.6, pp.1081-1088, 2003.

4) 可視化情報学会 (編) : PIV ハンドブック, 森北出版, 2002.

5）矢川元基，松浦真一，安藤良夫 : 点認識画像処理を用い た非接触ひずみ解析法，機械学会論文集 (A 編) , Vol.49, No.447, pp.1435-1443, 1983.

6) Choi, S. and Shah, S. P.: Measurement of deformations on concrete subjected to compression using image correlation, Experimental Mechanics, Vol.37, No.3, pp.307-313, 1997.

7) 渡辺 健, 東広憲, 三木明広, 二羽 淳一郎: コンクリート 構造実験を対象としたリアルタイム画像解析システムの 開発：土木学会論文集 E, Vol.66, No.1, pp.94-106, 2010.

8) 石丸 真，澤田昌孝，古関潤一，宮下千花 : 平面ひずみ圧 縮試験における不連続面を有する人工岩石材料の破壊進 展挙動，土木学会論文集 A2（応用力学）, Vol.67, No.2, pp.I_293-I_303, 2011.

9) 石井建樹, 田中健嗣, 伊藤智大, 清水敬太 : 多数の不連 続面を含む石亳供試体の圧縮破壊挙動，土木学会論文集 A2（応用力学）, Vol.67, No.2, pp.I_305-I_312, 2011.

10) 佐川康貴, 尾上幸造, 内野正和, 松下博通: 一軸圧縮力 を受けるモルタル供試体のひずみ計測へのデジタル画 像相関法の適用性に関する検討，実験力学，Vol.7, No.2, pp.114-120, 2007.

11) 野間康隆, 渡辺 健, 二羽 淳一郎：画像解析を用いた高 強度コンクリートの圧縮破壊進展評価，コンクリート工 学年次論文集, Vol.31, No.1, pp.523-528, 2009.

12) 出水享, 松田 浩, 伊藤幸広, 木村嘉富: デジタル画像 相関法を用いた撤去 PCT 桁橋の載荷試験時における変 位，ひずみ，ひび割れ計測，コンクリート工学年次論文 集, Vol.34, No.2, pp.1411-1416, 2012.

(2014. 6. 20 受付)

\section{STUDY OF IMAGE ANALYSIS METHODS FOR MEASURING CRACK PROPAGATION IN CONCRETE}

\section{Mao KURUMATANI, Jun MATSUURA, Shinobu NEMOTO and Zhishen WU}

Image analysis methods based on the digital image correlation (DIC) for measuring strain distribution together with crack propagation in concrete are developed in this paper. The hierarchical modeling in the DIC is introduced to construct high resolution grids of measurement. The tracking of material points and the updating of displacement vector using finite element interpolation are also introduced to increase the accuracy of the DIC. We first show the detail of our image analysis method based on the DIC. After the validation test of strain is performed, we apply the present method to compressive tests of mortar specimen and examine how to detect crack propagations clearly. Finally, the present method is applied to concrete to visualize the complicated crack propagations due to coarse aggregates. 